\title{
On-treatment mortality predictors in chronic hepatitis B patients experiencing severe acute exacerbation: a prospective observational study
}

\author{
Yi-Cheng Chen ${ }^{1}$, Chao-Wei Hsu ${ }^{1}$, Ming-Yang Chang ${ }^{2}$ and Chau-Ting Yeh ${ }^{1,3^{*}}$
}

\begin{abstract}
Background: Severe acute exacerbation in chronic hepatitis B could lead to mortality in some patients unless timely liver transplantation is performed. The baseline bilirubin level has been reported to be an important prognostic factor for mortality. Here we conducted a prospective observational study to examine the clinical performance of this predictor.
\end{abstract}

Method: Twenty-one consecutive chronic hepatitis B patients experiencing severe acute exacerbation were treated with either telbivudine or entecavir. The clinical characteristics at baseline and week- 2 were documented and correlated with mortality.

Results: Of the 21 patients included, 9 had baseline bilirubin $>10 \mathrm{mg} / \mathrm{dL}$. Four of these 9 patients (44.4\%) eventually died, whereas all other patients survived. During the initial 2-week period, the change of bilirubin was $-1.2 \mathrm{mg} / \mathrm{dl}$ in the survivors, but was $+8.05 \mathrm{mg} / \mathrm{dl}$ in the mortalities $(P=0.009)$. When this on-treatment factor was combined, 5 of the 21 patients had baseline bilirubin $>10 \mathrm{mg} / \mathrm{dL}$ plus an increase of bilirubin level at week-2. Of these 5 patients, 4 (80\%) died. Thus, by combining the baseline and on-treatment bilirubin levels, a positive predictive value of $80 \%$ and a negative predictive value of $100 \%$ could be achieved. Other significant on-treatment mortality predictors (at week-2) included higher international normalized ratio of prothrombin time (2.75 vs. 1.3, $P=0.004)$, higher model for end-stage liver disease score (30 vs. 17, $P=0.006)$, lower alpha-fetoprotein level ( 36.3 vs. $459.6 \mathrm{ng} / \mathrm{mL}, P=0.039$ ), and more rapid deterioration of the estimated glomerular filtration rate (eGFR) $(P=0.008)$. Interestingly, during the course, deterioration of eGFR was statistically significant in entecavir-treated $(P=0.028)$, but not in telbivudine-treated patients. Additionally, the patients treated with telbivudine had significant increase in serum alpha-fetoprotein ( 27.9 to $191.9 \mathrm{ng} / \mathrm{ml}, \mathrm{P}=0.046$ ) in the first 2 weeks, whereas the corresponding feature was not found in those treated with entecavir $(P=0.139)$.

Conclusions: In this prospective observational study, we discovered that the baseline and on-treatment bilirubin levels should be combined to achieve a better predictive value. Telbivudine might have a renoprotective effect in addition to its efficacy in viral suppression in patients with severe acute exacerbation.

Keywords: Severe acute exacerbation, Chronic hepatitis B, Alpha-fetoprotein, Estimated glomerular filtration rate

\footnotetext{
*Correspondence: chautingy@gmail.com

'Department of Gastroenterology-Hepatology, Liver Research Unit, Division

of Hepatology, Taipei, Taiwan

${ }^{3}$ Liver Research Center, Chang Gung Memorial Hospital, 199, Tung Hwa

North Road, Taipei, Taiwan

Full list of author information is available at the end of the article
} 


\section{Background}

Severe acute exacerbation (SAE) is not uncommon in the natural course of chronic hepatitis $B$ virus (HBV) infection, characterized by high serum alanine aminotransferase (ALT) level, jaundice, coagulopathy and hepatic decompensation [1-4]. The prognosis is poor with a high mortality of $65-93 \%$ once hepatic encephalopathy has occurred [4-6]. Thus, timely liver transplantation is indicated. The prognostic factors for mortality include high serum bilirubin level, thrombocytopenia or liver cirrhosis, prolonged prothrombin time or high international normalized ratio (INR) of prothrombin time, low serum albumin level at baseline and emergence of ascites or encephalopathy during the course [3,7-9]. However, because of the retrospective nature of these studies, our knowledge regarding the clinical usefulness of ontreatment factors in predicting mortality is very limited. Furthermore, more and more potent antiviral drugs are now approved for clinical use. Conceivably, effective antiviral therapy would improve the survival of patients with SAE and thus change the predictivity of previously identified factors.

Lamivudine, a nucleoside analogue with inhibitory effects on HBV polymerase/reverse transcriptase activity, has been used as a rescue therapy for SAE in chronic hepatitis $B$ patients. However, the mortality rate remains high, which varies from 13.5 to $38 \%$ in studies from different populations [3,7-11]. Entecavir (ETV) is a potent inhibitor of HBV DNA polymerase with a high resistance barrier and Telbivudine (LdT) is an orally bioavailable L-nucleoside with rapid HBV suppression activity. Both have been approved for treatment of chronic hepatitis $B$ and have superior antiviral activity to lamivudine [12-15]. ETV has been used in decompensated chronic hepatitis B in clinical trials [16,17] as well as in clinical practices $[18,19]$ with satisfactory safety profile and tolerability. On the other hand, the results from a 2-year randomized clinical trial in treatment of decompensated HBV-related cirrhosis also showed that LdT was well tolerated and the treatment led to stabilization of liver function [20]. Despite the availability of these evidences, the clinical data regarding LdT usage in chronic hepatitis $B$ patients with SAE remain scanty.

Since all prognostic predictors for mortality are obtained from retrospective studies, it is unclear whether the performance of these predictors is satisfactory in real world, especially when patients with SAE are now being treated with potent antiviral drugs. Of the baseline prognostic predictors, bilirubin level has been repeatedly reported to be an important factor for mortality. In this prospective observational study, we treated the SAE patients with either ETV or LdT and examined the performance of the baseline bilirubin level together with other mortality predictors. Additionally, we explored the early on-treatment factors as accessory predictive factors for mortality.

\section{Methods}

This was an open label, prospective observational study of patients with chronic hepatitis B, admitted for spontaneous SAE to Chang Gung Memorial Hospital since July 2009. The study was approved by the Institutional Review Board of Chang Gung Medical Center and written informed consent was obtained from all patients enrolled. The SAE of chronic hepatitis B was defined as elevation of ALT to greater than five times of upper limit of normal (ULN, $36 \mathrm{U} / \mathrm{L}$ ) with serum total bilirubin level greater than $2 \mathrm{mg} / \mathrm{dL}$ and $\mathrm{INR} \geq 1.3$. The antiviral therapy with nucleoside analogue was given under the coverage of the national health insurance in Taiwan, because of the clinical status of hepatic decompensation. Patients with coinfection of hepatitis $C$ virus, hepatitis D virus or human immunodeficiency virus and alcoholic liver disease were excluded.

Twenty-one consecutive patients fulfilling the definition of SAE, treated with $\mathrm{LdT} 600 \mathrm{mg} /$ day $(\mathrm{n}=9$ ) or ETV $0.5 \mathrm{mg} /$ day $(\mathrm{n}=12)$, were included in this study. All antiviral treatments were initiated within 1 week of symptom onset. No antiviral treatment had been given prior to the onset of this SAE. The decision of antiviral drug was made by each patient and physician after discussion. The factors under consideration included risk of resistance, oncogenic potential in animal study, and possible renal function preservation. All patients were followed at baseline, weeks 2, 4, 8, 12 and then every 3 months for liver biochemistry, INR, alfa-fetoprotein (AFP), creatinine and estimated glomerular filtration rate (eGFR). Model for end-stage liver disease (MELD) was calculated as described in the literature [21] at the corresponding time points. The eGFR was calculated by modification of diet in renal disease (MDRD) formula [22] and Chronic Kidney Disease Epidemiology Collaboration (CKD-EPI) creatinine equation [23]. Serum HBV DNA was tested at baseline, weeks 2, 4, 12 and then every 3 months using a standardized automated quantitative polymerase chain reaction assay (Roche COBAS TaqMan HBV Test, Roche Diagnostics, Pleasanton, CA) with a detection range of 69 to $6.402 \times 10^{6}$ copies $/ \mathrm{mL}$.

Statistical analyses were performed by Statistical Package for Social Science Statistics (SPSS Statistics, version 17.0, Chicago, IL, USA). Continuous variables were expressed as median (range) and were compared by Mann-Whitney U test. Categorical variables were compared by Chi-square test or Fisher's exact test as appropriate. HBV DNA level was logarithmic transformed for analysis. The paired comparison of two relative variables was performed by Wilcoxon signed rank test. $\mathrm{P}<0.05$ was considered statistically significant. 


\section{Results}

The baseline and week-2 clinical parameters associated with mortality

The median (range) age was $48(28-71)$ years and 18 (86\%) were males. The median (range) follow-up period was 19.4 (0.8-28.2) months. All patients had a known history of chronic hepatitis B with positive serum HBV surface antigen ( $\mathrm{HBsAg}$ ) detected at least 1 year before SAE. All patients were negative for IgM class anti-HBV core antibody. Three patients had liver cirrhosis at the time of SAE and three had ascites due to liver failure. Four patients died at the time of 0.8, 1.0, 1.9 and 2.5 months during follow-up with 1-month and 3-month mortality rate of $9.5 \%$ and $19 \%$, respectively. The overall mortality rate was 19\% (2 with LdT, 22.2\%; 2 with ETV, 16.7\%).

The median levels of serum total bilirubin, INR and MELD scores at baseline in the mortalities were $20.6 \mathrm{mg} / \mathrm{dL}, 3.3$ and 31.5, respectively. These were significantly higher than the corresponding figures in those who survived $(7.7 \mathrm{mg} / \mathrm{dL}, \mathrm{P}=0.007 ; 1.5, \mathrm{P}=0.002$; and $19, \mathrm{P}=0.003$, respectively). The difference was also statistically significant in serum albumin (2.95 vs. $3.6 \mathrm{mg} / \mathrm{dL}, \mathrm{P}=0.020$ ) and HBV DNA level (5.06 vs. $8.16 \log _{10}$ copies $/ \mathrm{mL}, \mathrm{P}=0.031$ ) between patients with mortality and survival, as shown in Table 1 . The serum ALT, creatinine, eGFR by MDRD and CKD-EPI, platelet count and AFP were not statistically different in the mortalities and survivals.

At week 2, patients with mortality had significantly higher serum total bilirubin $(29.1$ vs. $4.8 \mathrm{mg} / \mathrm{dL}$, $\mathrm{P}=0.003)$, INR (2.75 vs. $1.3, \mathrm{P}=0.004)$ and MELD score $(30$ vs. $17, \mathrm{P}=0.006)$ than the corresponding figures of those who survived. On the contrary, the survival patients had significantly higher AFP (459.6 vs. $36.3 \mathrm{ng} / \mathrm{mL}, \mathrm{P}=0.039$ ), as shown in Table 2 . There was no significant difference in serum ALT, creatinine, eGFR (MDRD and CKD-EPI) and HBV DNA levels at week 2 between the survivals and the mortalities.

Table 1 Baseline clinical characteristics by different outcomes and treatment groups

\begin{tabular}{|c|c|c|c|c|c|c|c|}
\hline Patient no & $\begin{array}{l}\text { All } \\
21\end{array}$ & $\begin{array}{c}\text { Survival } \\
17\end{array}$ & $\begin{array}{c}\text { Mortality } \\
4\end{array}$ & $p$ & $\begin{array}{c}\text { Telbivudine } \\
9\end{array}$ & $\begin{array}{c}\text { Entecavir } \\
12\end{array}$ & $p$ \\
\hline Age & $48(28-71)$ & $49(28-71)$ & $36.5(29-51)$ & 0.226 & $48(29-65)$ & $47(28-71)$ & 0.859 \\
\hline Gender & & & & 1.000 & & & 1.000 \\
\hline Male & 18 & 14 & 4 & & 8 & 10 & \\
\hline Female & 3 & 3 & 0 & & 1 & 2 & \\
\hline LdT/ETV & $9 / 12$ & $7 / 10$ & $2 / 2$ & 1.000 & - & - & - \\
\hline Mortality & - & - & - & - & 2 & 2 & 1.000 \\
\hline $\mathrm{HBeAg}+$ & 9 & 7 & 2 & 1.000 & 3 & 6 & 0.660 \\
\hline Cirrhosis & 3 & 2 & 1 & 0.489 & 1 & 2 & 1.000 \\
\hline Ascites & 3 & 1 & 2 & 0.080 & 1 & 2 & 1.000 \\
\hline Encephalopathy & 1 & 1 & 0 & 0.190 & 1 & 0 & 0.429 \\
\hline $\mathrm{FU}(\mathrm{M})$ & $19.4(0.8-28.2)$ & $25.0(4.0-28.2)$ & $1.45(0.8-2.5)$ & 0.002 & $5.1(1.9-28.2)$ & $24.7(0.8-27.7)$ & 0.722 \\
\hline Albumin & $3.49(2.5-4.9)$ & $3.6(2.5-4.9)$ & $2.95(2.5-3.3)$ & 0.020 & $3.6(2.9-4.2)$ & $3.4(2.5-4.9)$ & 0.477 \\
\hline ALT & $1270(146-2480)$ & $1270(211-2480)$ & $1197(146-2247)$ & 0.929 & $1523(211-2480)$ & $870(146-2247)$ & 0.177 \\
\hline Bilirubin $T$ & $9.2(2.1-33.1)$ & $7.7(2.1-16.8)$ & $20.6(11.9-33.1)$ & 0.007 & $8.6(2.1-20.4)$ & $10.25(2.2-33.1)$ & 0.356 \\
\hline Creatinine & $0.68(0.39-1.46)$ & $0.71(0.47-1.34)$ & $0.48(0.39-1.46)$ & 0.165 & $0.71(0.47-1.05)$ & $0.63(0.39-1.46)$ & 0.972 \\
\hline \multicolumn{8}{|l|}{ eGFR } \\
\hline MDRD & $116(53-254)$ & $116(53-183)$ & $194.5(54-254)$ & 0.106 & $116(73-201)$ & $127(53-254)$ & 0.831 \\
\hline CKD-EPI & $111.1(52.9-156.7)$ & $110.1(52.9-131.1)$ & $138.2(59.8-156.7)$ & 0.152 & $112(77.8-148)$ & $110.6(52.9-156.7)$ & 0.722 \\
\hline Platelet $\left(10^{3}\right)$ & $148(44-253)$ & $148(62-253)$ & $121.5(44-174)$ & 0.244 & $174(44-251)$ & $121.5(62-253)$ & 0.188 \\
\hline INR & $1.6(1.3-3.5)$ & $1.5(1.3-2.3)$ & $3.3(2.6-3.5)$ & 0.002 & $1.5(1.3-3.1)$ & $1.6(1.4-3.5)$ & 0.773 \\
\hline AFP & $65.7(4.1-650.7)$ & $49.4(4.1-477.2)$ & $109.5(27.9-650.7)$ & 0.325 & $27.9(4.2-238.3)$ & $162.1(4.1-650.7)$ & 0.088 \\
\hline HBV DNA $\left(\log _{10} \mathrm{cps} / \mathrm{ml}\right)$ & $8.04(4.3-9.68)$ & $8.16(5.22-9.68)$ & $5.06(4.30-8.20)$ & 0.031 & $8.04(4.97-9.47)$ & $8.04(4.30-9.68)$ & 0.886 \\
\hline MELD score & $20(13-37)$ & 19 (13-28) & $31.5(26-37)$ & 0.003 & $19(14-31)$ & $20(13-37)$ & 0.412 \\
\hline
\end{tabular}

Data shown as median (range); eGFR estimated glomerular filtration rate, MDRD modification of diet in renal disease $\left(\mathrm{mL} / \mathrm{min} / 1.73 \mathrm{~m}^{2}\right.$ ), $C K D$-EPI Chronic Kidney Disease Epidemiology Collaboration $\left(\mathrm{mL} / \mathrm{min} / 1.73 \mathrm{~m}^{2}\right)$, INR international normalized ratio, AFP alpha-fetoprotein, MELD model for end-stage liver disease. 
Table 2 Paired comparison of clinical parameters between baseline and week 2 in different outcomes and treatment groups

\begin{tabular}{|c|c|c|c|c|c|c|c|c|c|c|c|c|c|c|c|}
\hline \multirow{3}{*}{$\begin{array}{l}\text { Patient no } \\
\text { Time point }\end{array}$} & \multicolumn{2}{|c|}{ Overall } & \multirow[b]{3}{*}{$p$} & \multicolumn{2}{|c|}{ Survival } & \multirow[b]{3}{*}{$p$} & \multicolumn{2}{|c|}{ Mortality } & \multirow[b]{3}{*}{$\mathbf{P}$} & \multirow{2}{*}{\multicolumn{2}{|c|}{$\begin{array}{c}\text { Telbivudine } \\
9\end{array}$}} & \multirow[b]{3}{*}{$p$} & \multirow{2}{*}{\multicolumn{2}{|c|}{$\begin{array}{c}\text { Entecavir } \\
12\end{array}$}} & \multirow[b]{3}{*}{$p$} \\
\hline & \multicolumn{2}{|c|}{21} & & \multicolumn{2}{|c|}{17} & & \multicolumn{2}{|c|}{4} & & & & & & & \\
\hline & Baseline & Week 2 & & Baseline & Week $2^{\mathrm{a}}$ & & Baseline & Week $2^{a}$ & & Baseline & Week $2^{b}$ & & Baseline & Week $2^{b}$ & \\
\hline$\overline{\mathrm{ALT}}$ & $\begin{array}{c}1270 \\
(146-2480)\end{array}$ & $\begin{array}{c}167 \\
(41-485)\end{array}$ & $<0.001$ & $\begin{array}{c}1270 \\
(211-2480)\end{array}$ & $\begin{array}{c}184 \\
(41-485)\end{array}$ & $<0.001$ & $\begin{array}{c}1197 \\
(146-2247)\end{array}$ & $\begin{array}{c}112.5 \\
(66-190)\end{array}$ & 0.068 & $\begin{array}{c}1523 \\
(211-2480)\end{array}$ & $\begin{array}{c}184 \\
(80-435)\end{array}$ & 0.011 & $\begin{array}{c}870 \\
(146-2247)\end{array}$ & $\begin{array}{c}133.5 \\
(41-485)\end{array}$ & 0.002 \\
\hline
\end{tabular}

\begin{tabular}{|c|c|c|c|c|c|c|c|c|c|c|c|c|c|c|c|}
\hline Bilirubin T & $\begin{array}{c}9.2 \\
(2.1-33.1)\end{array}$ & $\begin{array}{c}6.8 \\
(1.8-43.2)\end{array}$ & 0.728 & $\begin{array}{c}7.7 \\
(2.1-16.8)\end{array}$ & $4.8(1.8-21.3)$ & 0.309 & $20.6(11.9-33.1)$ & $\begin{array}{c}29.1 \\
(17.8-43.2)\end{array}$ & 0.068 & $\begin{array}{c}8.6 \\
(2.1-20.4)\end{array}$ & $8.0(1.9-25.3)$ & 0.515 & $\begin{array}{c}10.25 \\
(2.2-33.1)\end{array}$ & $\begin{array}{c}5.15 \\
(1.8-43.2)\end{array}$ & 1.000 \\
\hline Creatinine & $\begin{array}{c}0.68 \\
(0.39-1.46)\end{array}$ & $\begin{array}{c}0.94 \\
(0.37-3.79)\end{array}$ & 0.002 & $\begin{array}{c}0.71 \\
(0.47-1.34)\end{array}$ & $\begin{array}{c}1.0 \\
(0.37-1.81)\end{array}$ & 0.019 & $\begin{array}{c}0.48 \\
(0.39-1.46)\end{array}$ & $\begin{array}{c}0.92 \\
(0.72-3.79)\end{array}$ & 0.068 & $\begin{array}{c}0.71 \\
(0.47-1.05)\end{array}$ & $\begin{array}{c}0.90 \\
(0.59-1.49)\end{array}$ & 0.051 & $\begin{array}{c}0.63 \\
(0.39-1.46)\end{array}$ & $\begin{array}{c}1.03 \\
(0.37-3.79)\end{array}$ & 0.021 \\
\hline \multicolumn{16}{|l|}{ eGFR } \\
\hline MDRD & $\begin{array}{c}116 \\
(53-254)\end{array}$ & $\begin{array}{c}89 \\
(18-241)\end{array}$ & 0.005 & $\begin{array}{c}116 \\
(53-183)\end{array}$ & $77(37-241)$ & 0.042 & 194.5 (54-254) & $\begin{array}{c}90.5 \\
(18-129)\end{array}$ & 0.068 & $\begin{array}{c}116 \\
(73-201)\end{array}$ & $89(37-147)$ & 0.044 & $\begin{array}{c}127 \\
(53-254)\end{array}$ & $\begin{array}{c}79 \\
(18-241)\end{array}$ & 0.050 \\
\hline CKD-EPI & $\begin{array}{c}111.1 \\
(52.9-156.7)\end{array}$ & $\begin{array}{c}98.3 \\
(18.9-134.5)\end{array}$ & 0.003 & $\begin{array}{c}110.1 \\
(52.9-131.1)\end{array}$ & $\begin{array}{c}82.9 \\
(36.8-134.5)\end{array}$ & 0.028 & $\begin{array}{c}138.2 \\
(59.8-156.7)\end{array}$ & $\begin{array}{c}101.8 \\
(18.9-126.4)\end{array}$ & 0.068 & $\begin{array}{c}112 \\
(77.8-148)\end{array}$ & $\begin{array}{c}98.3 \\
(40.9-126.4)\end{array}$ & 0.066 & $\begin{array}{c}110.6 \\
(5.29-56.7)\end{array}$ & $\begin{array}{c}86.9 \\
(18.9-134.5)\end{array}$ & 28 \\
\hline INR & $1.6(1.3-3.5)$ & $1.4(1.0-4.2)$ & 0.066 & $1.5(1.3-2.3)$ & $1.3(1.0-2.8)$ & 0.062 & $3.3(2.6-3.5)$ & $\begin{array}{c}2.75 \\
(2.2-4.2)\end{array}$ & 0.577 & $\begin{array}{c}1.5 \\
(1.3-3.1)\end{array}$ & $1.7(1.1-2.8)$ & 0.440 & $\begin{array}{c}1.6 \\
(1.4-3.5)\end{array}$ & $\begin{array}{c}1.35 \\
(1.0-4.2)\end{array}$ & .058 \\
\hline AFP & $\begin{array}{c}65.7 \\
(4.1-650.7)\end{array}$ & $\begin{array}{c}305.5 \\
(6.2-2802)\end{array}$ & 0.013 & $\begin{array}{c}49.4 \\
(4.1-477.2)\end{array}$ & $\begin{array}{c}459.6 \\
(35.4-2802)\end{array}$ & 0.005 & $\begin{array}{c}109.5 \\
(27.9-650.7)\end{array}$ & $\begin{array}{c}36.3 \\
(6.2-66.3)\end{array}$ & 0.180 & $\begin{array}{c}27.9 \\
(4.2-238.3)\end{array}$ & $\begin{array}{c}191.9 \\
(66.3-1462.5)\end{array}$ & 0.046 & $\begin{array}{c}162.1 \\
(4.1-650.7)\end{array}$ & $\begin{array}{c}459.6 \\
(6.2-2802)\end{array}$ & 0.139 \\
\hline HBV DNA $\left(\log _{10} \mathrm{cps} / \mathrm{ml}\right)$ & $\begin{array}{c}8.04 \\
(4.3-9.68)\end{array}$ & $\begin{array}{c}4.19 \\
(3.07-5.89)\end{array}$ & $<0.001$ & $\begin{array}{c}8.16 \\
(5.22-5.06)\end{array}$ & $\begin{array}{c}4.2 \\
(3.07-5.89)\end{array}$ & 0.001 & $5.06(4.3-8.2)$ & $\begin{array}{c}3.64 \\
(3.31-3.96)\end{array}$ & 0.180 & $\begin{array}{c}8.04 \\
(4.97-9.47)\end{array}$ & $\begin{array}{c}3.96 \\
(3.07-5.10)\end{array}$ & 0.018 & $\begin{array}{c}8.04 \\
(4.30-9.68)\end{array}$ & $\begin{array}{c}4.20 \\
(3.13-5.89)\end{array}$ & 0.005 \\
\hline MELD score & $20(13-37)$ & $19(11-49)$ & 0.283 & $19(13-28)$ & $17(11-32)$ & 0.166 & $31.5(26-.7)$ & $30(26-49)$ & 0.655 & $19(14-31)$ & $20(11-32)$ & 0.674 & $20(13-37)$ & $18(11-49)$ & 0.469 \\
\hline
\end{tabular}

Data shown as median (range); eGFR estimated glomerular filtration rate, MDRD modification of diet in renal disease ( $\mathrm{mL} / \mathrm{min} / 1.73 \mathrm{~m}^{2}$ ), CKD-EPI Chronic Kidney Disease Epidemiology Collaboration (mL/min/1.73m²), INR

international normalized ratio, AFP alpha-fetoprotein, MELD model for end-stage liver disease.
$a$ : comparison of week 2 data between survival and mortality, $\mathrm{p}$ values in order were $0.324,0.003,0.720,0.788,1.000,0.004,0.039,0.160,0.006$.

: comparison of week 2 data between survival and mortality, $\mathrm{p}$ values in order were $0.324,0.003,0.720,0.788,1.000,0.004,0.039,0.160,0.006$ 


\section{Changes of clinical parameters between baseline and week-2 for all patients}

To understand the progressive changes of clinical parameters during the treatment course, comparison of clinical factors at baseline and week 2 for all patients was performed (Table 2). The serum ALT and HBV DNA decreased significantly (1270 to $167 \mathrm{U} / \mathrm{L}, \mathrm{P}<0.001$ and 8.04 to $4.19 \log _{10}$ copies $/ \mathrm{mL}, \mathrm{P}<0.001$, respectively) in the first 2-week of antiviral treatment with paired comparison (Table 2). The serum creatinine increased significantly from baseline to week 2 (0.68 to $0.94 \mathrm{mg} / \mathrm{dL}, \mathrm{P}=0.002$ ) despite of treatment. Correspondingly, the eGFR calculated by MDRD (116 to $89 \mathrm{~mL} / \mathrm{min} / 1.73 \mathrm{~m}^{2}, \mathrm{P}=0.005$ ) and CKD-EPI (111.1 to $98.3 \mathrm{~mL} / \mathrm{min} / 1.73 \mathrm{~m}^{2}, \mathrm{P}=0.003$ ) decreased significantly during the 2 -week period. The AFP increased significantly $(65.7$ to $305.5 \mathrm{ng} / \mathrm{mL}$, $\mathrm{P}=0.013$ ) from baseline to week 2 . There was no significant difference between baseline and week 2 in serum total bilirubin, INR and MELD score.

Similar progressive changes for all the clinical parameters were found in the survival group, including the declines in serum ALT and HBV DNA levels (1270 to $184 \mathrm{U} / \mathrm{L}, \mathrm{P}<0.001$ and 8.16 to $4.2 \log _{10}$ copies $/ \mathrm{mL}$, $\mathrm{P}=0.001$, respectively), the increases of serum creatinine $(0.71$ to $1.0 \mathrm{mg} / \mathrm{dL}, \mathrm{P}=0.019)$ and decreases of eGFR (MDRD, 113.5 to $76 \mathrm{~mL} / \mathrm{min} / 1.73 \mathrm{~m}^{2}, \mathrm{P}=0.042$; CKD-EPI, 110.1 to $\left.82.9 \mathrm{~mL} / \mathrm{min} / 1.73 \mathrm{~m}^{2}, \mathrm{P}=0.028\right)$, and the increases of AFP (49.4 to $459.6 \mathrm{ng} / \mathrm{mL}, \mathrm{P}=0.005$ ) (Table 2).

The changes $(\Delta)$ of parameters between baseline and the week 2 time point in association with mortality

When comparing the parameters in terms of the changes $(\Delta)$ from baseline to week 2 , the mortalities had significantly greater increase in serum total bilirubin $(\Delta=+8.05$ vs $-1.2 \mathrm{mg} / \mathrm{dL}, \mathrm{P}=0.009)$ and creatinine $(\Delta=0.49$ vs $0.08 \mathrm{mg} / \mathrm{dL}, \mathrm{P}=0.049)$ levels, and more rapid decrease in eGFR (MDRD, $\Delta=-85.5 \mathrm{vs}-16 \mathrm{~mL} /$ $\min / 1.73 \mathrm{~m}^{2}, \mathrm{P}=0.008$; CKD-EPI, $\Delta=-35.5 \mathrm{vs}-6.0 \mathrm{~mL} /$ $\min / 1.73 \mathrm{~m}^{2}, \mathrm{P}=0.049$ ) (Figure 1 ). The serum AFP increased in the survivals $(\Delta=184.2 \mathrm{ng} / \mathrm{ml})$ but decreased in the mortalities $(\Delta=-73.2 \mathrm{ng} / \mathrm{ml})$ with marginal significance $(\mathrm{P}=0.057)$. The survivals had HBV DNA decline of $3.4 \log \mathrm{IU} / \mathrm{mL}$ and only $1.4 \log \mathrm{IU} / \mathrm{mL}$ in the mortalities $(\mathrm{P}=0.074)$ (Table 3$)$.

Of the 17 survivors, 5 had bilirubin $>10 \mathrm{mg} / \mathrm{dL}$ at baseline, a feature predicting high mortality according to previous studies [7-9]. As such, only 4 of 9 (44.4\%) with baseline bilirubin level $>10 \mathrm{mg} / \mathrm{dL}$ resulted in mortality. The positive predictive value (PPV) using only baseline bilirubin level was $44.4 \%$.

However, of these 9 patients, 4 of them showed decrease of bilirubin levels at week 2 and all these 4 patients survived (Figure 2). By using baseline bilirubin $>10 \mathrm{mg} / \mathrm{dL}$,

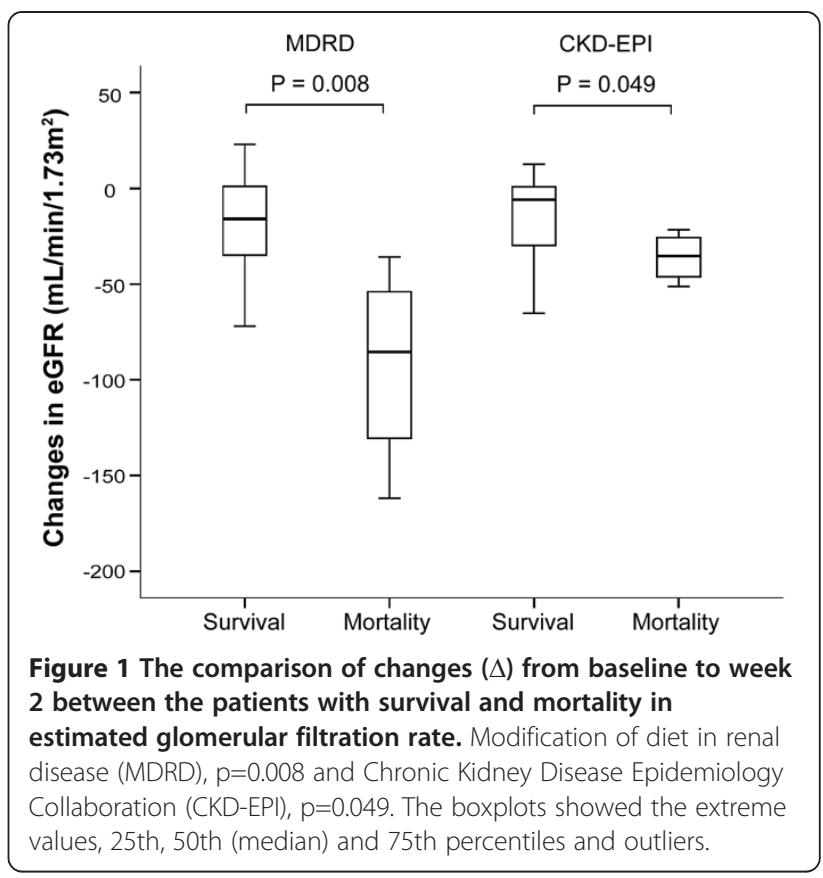

combined with increase of bilirubin levels during the first 2-week period, 5 patients meeting these two criteria were identified. Four of these 5 patients resulted in mortality. The positive predictive value (PPV) was $80 \%$ and the negative predictive value (NPV) was $100 \%$ by use of the combination criteria.

\section{The efficacy of viral suppression and change of renal function in LdT and ETV treated patients}

Of these patients, 9 were treated with LdT and 12 received ETV immediately after the diagnosis of chronic B hepatitis with SAE. As shown in Table 1, the baseline clinical characteristics were similar in patients receiving LdT and ETV. After 2 weeks of treatment, there was no statistical difference in the clinical parameters between the two treatment groups (Table 2). Two deaths occurred in each group (by 1.9, 2.5 months in LdT group and 0.8, 1.0 months in ETV group) during follow-up without significant difference in mortality rate $(\mathrm{P}=1.000)$ (Table 1$)$. Both LdT and ETV showed excellent effects on declines in serum ALT (1523 to $184 \mathrm{U} / \mathrm{L}, \mathrm{P}=0.011$ and 870 to 133.5 U/L, $\mathrm{P}=0.002$, respectively) and HBV DNA levels (8.04 to $3.96 \log _{10}$ copies $/ \mathrm{mL}, \mathrm{P}=0.018$ and 8.04 to $4.20 \log _{10}$ copies $/ \mathrm{mL}, \mathrm{P}=0.005$, respectively) in the initial 2-week period of treatment. The patients treated with LdT had significant increase in serum AFP (27.9 to 191.9 $\mathrm{ng} / \mathrm{ml}, \mathrm{P}=0.046)$ in 2 weeks, whereas the corresponding feature was not found in those with ETV treatment $(\mathrm{P}=0.139)$.

Although serum creatinine levels at week 2 were higher than those at baseline in both LdT and ETV groups, the difference was statistically significant in ETV 
Table 3 The changes $(\Delta)$ of clinical parameters from baseline to week 2 in different outcomes and treatment groups

\begin{tabular}{|c|c|c|c|c|c|c|c|}
\hline & All & Survival & Mortality & $p$ & Telbivudine & Entecavir & $p$ \\
\hline Patient no & 21 & 17 & 4 & & 9 & 12 & \\
\hline$\overline{\mathrm{ALT}}$ & $-1161(-2313-+106)$ & $-1161(-2313-+106)$ & $-890(-2057-44)$ & 1.000 & $\begin{array}{c}-1383 \\
(-2313-+106)\end{array}$ & $-547.5(-2057--30)$ & 0.256 \\
\hline Bilirubin $T$ & $-0.4(-9.1-+12.2)$ & $-1.2(-9.1-+11.5)$ & $8.05(5.9-12.2)$ & 0.009 & $-0.9(-6-+11.5)$ & $-0.3(-9.1-+12.2)$ & 0.722 \\
\hline Creatinine & $0.22(-0.1-+2.33)$ & $0.08(-0.10-+0.87)$ & $0.49(0.23-2.33)$ & 0.049 & $0.22(-0.09-+0.87)$ & $0.27(-0.1-+2.33)$ & 0.594 \\
\hline \multicolumn{8}{|l|}{ eGFR } \\
\hline MDRD & $-23(-162-+58)$ & $-16(-72-+58)$ & $-85.5(-162--36)$ & 0.008 & $-23(-99-+23)$ & $-23(-162-+58)$ & 0.749 \\
\hline CKD-EPI & $-16.1(-65.2-+12.6)$ & $-6.0(-65.2-+12.6)$ & $-35.5(-51.3--21.7)$ & 0.049 & $-21.1(-65.2-+6.81)$ & $-13.0(-51.3-+12.6)$ & 0.776 \\
\hline INR & $-0.3(-1.0-+0.9)$ & $-0.3(-1.0-+0.9)$ & $-0.4(-0.5-+0.7)$ & 0.318 & $-0.3(-0.6-+0.9)$ & $-0.3(-1.0-+0.7)$ & 0.971 \\
\hline AFP & $\begin{array}{c}151.5 \\
(-140.7-+2326.6)\end{array}$ & $\begin{array}{c}184.2 \\
(-110.2-+2326.6)\end{array}$ & $-73.2(-140.7--5.8)$ & 0.057 & $\begin{array}{c}184.2 \\
(-5.8-+1385.9)\end{array}$ & $101.2(-140.7-+2326.6)$ & 0.386 \\
\hline HBV DNA $\left(\log _{10} \mathrm{cps} / \mathrm{ml}\right)$ & $-3.27(-5.47--0.55)$ & $-3.4(-5.5--0.6)$ & $-1.4(-1.8--1.0)$ & 0.074 & $-3.4(-5.0--1.0)$ & $-3.0(-5.5--0.6)$ & 0.922 \\
\hline MELD score & $-1.0(-11-+14)$ & $-1.0(-11-+14)$ & $0.0(-1-+12)$ & 0.344 & $-1.0(-6-+14)$ & $-0.5(-11-+12)$ & 0.775 \\
\hline
\end{tabular}

Data shown as median (range); eGFR estimated glomerular filtration rate, MDRD modification of diet in renal disease (mL/min/1.73m²), CKD-EPI Chronic Kidney Disease Epidemiology Collaboration $\left(\mathrm{mL} / \mathrm{min} / 1.73 \mathrm{~m}^{2}\right)$, INR international normalized ratio, AFP alpha-fetoprotein, MELD model for end-stage liver disease.

group (0.63 to $1.03 \mathrm{mg} / \mathrm{dL}, \mathrm{P}=0.021)$, but not in $\mathrm{LdT}$ group ( 0.71 to $0.9 \mathrm{mg} / \mathrm{dL}, \mathrm{P}=0.051$ ). The decrease of eGFR using MDRD formula was significant in the LdT group (116 to $89 \mathrm{~mL} / \mathrm{min} / 1.73 \mathrm{~m}^{2}, \mathrm{P}=0.044$ ) but not the ETV group (127 to $\left.79 \mathrm{~mL} / \mathrm{min} / 1.73 \mathrm{~m}^{2}, \mathrm{P}=0.050\right)$. The decrease of eGFR using CKD-EPI equation was also statistically significant in ETV group (110.6 to $86.9 \mathrm{~mL} / \mathrm{min} /$ $\left.1.73 \mathrm{~m}^{2}, \mathrm{P}=0.028\right)$, but not in LdT group (112 to $98.3 \mathrm{~mL} /$ $\left.\min / 1.73 \mathrm{~m}^{2}, \mathrm{P}=0.066\right)$. The changes $(\Delta)$ from baseline to week 2 in serum ALT, total bilirubin, creatinine, eGFR (MDRD and CKD-EPI), INR, AFP, HBV DNA level and MELD score were similar in LdT and ETV groups without statistically significance (Table 3).

Until the last visits, all survived patients were uneventful during follow-up and no drug-resistance was found in patients treated with LdT.

\section{Discussion}

This prospective observational study revealed not only the baseline but also the on-treatment predictors for mortality of chronic hepatitis B patients with hepatic decompensation secondary to SAE. In consistent with previous studies [3,7-9], the patients with mortality had significantly lower serum albumin, higher total bilirubin level and INR at baseline. The present study also showed significantly higher baseline MELD score in patients with mortality. At the week 2 time point, the serum total bilirubin, INR and MELD scores were significantly lower and AFP was significantly higher in the survivors (Table 2). The present results indicated that decreasing serum total bilirubin, INR and MELD score and increasing serum AFP at week 2 were good indicators for survival in SAE of chronic hepatitis B. In the meanwhile, it was noted that an increase in

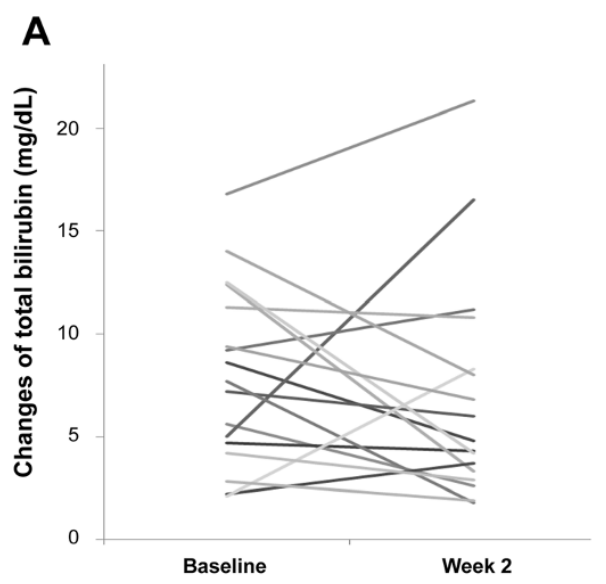

B

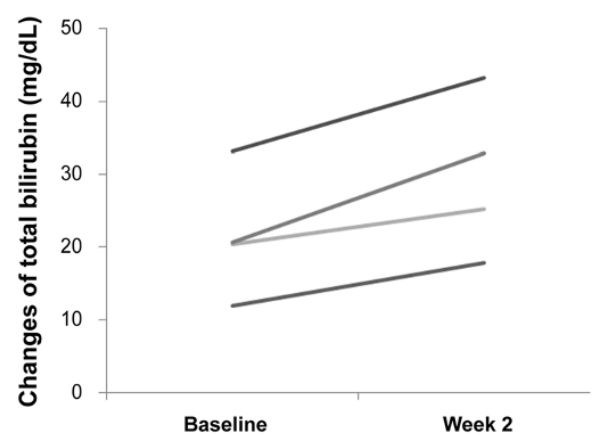

Figure 2 The graphical presentations of total bilirubin levels from baseline to week 2 in (A) 17 survivors and (B) 4 mortalities. 
serum total bilirubin (baseline to week-2) in the patients combined with baseline bilirubin $>10 \mathrm{mg} / \mathrm{dl}$ had the PPV of $80 \%$ for mortality, while the NPV was $100 \%$ for decreasing serum total bilirubin in the 2-week period. The overall mortality rate was $19 \%$ which was higher than that of a recent study in Hong Kong [19], but was lower when compared with the studies using lamivudine or tenofovir treatment $[3,7,8,24]$. The different study populations and timing to begin antiviral therapy may lead to this discrepancy.

Previous studies have shown that the HBV DNA level at the time of SAE had little correlation with short-term mortality [3,7-9,19]. However, the baseline HBV DNA level was significantly lower in patients with mortality in the present study. It might be attributive to the enhanced immune response in SAE, which led to massive hepatocellular necrosis and clearance of the majority of HBV. The results of aggravated liver injury and decreased liver reservation could increase the chance of mortality. At week 2, the HBV DNA levels were comparable between patients with survival and mortality, but the decline from baseline to week 2 was marginally greater in the survival patients (Table 3). Both LdT and ETV had excellent efficacy in viral suppression to high but not to low viral load at baseline. The virological decline was around $3 \log _{10} \mathrm{IU} / \mathrm{mL}$ during 2 -week period of LdT and ETV treatment. The rate of viral suppression was faster when compared with previous studies [12-15].

Serum AFP has been a marker of bridging hepatic necrosis in acute exacerbation of chronic hepatitis B when it is greater than $100 \mathrm{ng} / \mathrm{mL}$ [25], and an increasing level suggests the occurrence of hepatic regeneration in acute hepatitis or after partial hepatectomy [26,27]. Previous studies showed that decreasing serum AFP levels predicted poor prognosis of acute hepatic failure in patients with chronic hepatitis B and an increase in AFP level was strongly associated with a favorable outcome in patients with acetaminophen-induced liver injury [28,29]. The data in present study revealed that serum AFP levels in survival patients at week 2 were significantly greater than those in patients with mortality. It therefore could be inferred that the patients with increasing AFP levels likely had good hepatic regeneration and reservation and were able to survive in the SAE of chronic hepatitis B. However, the reason for significantly greater increase in AFP from baseline to week 2 in patients treated with LdT was unknown. But this could suggest that liver regeneration might be better under LdT treatment.

The deterioration of renal function is a prognostic factor indicating poor prognosis in liver disease [30]. In the present study, the serum creatinine was significantly higher at week 2 than at baseline with correspondingly significant decrease in eGFR by MDRD and CKD-EPI in all patients (Table 2). It meant that renal dysfunction did occur at the early stage of liver decompensation resulting from SAE. In view of the change $(\Delta)$ from baseline to week 2 , the deterioration of renal function was greater in those with mortality (Table 3 ). These results indicated that follow-up of serum creatinine with accompanied eGFR calculation is important in acute decompensated hepatitis patients for prediction of short term mortality and early preparation for liver transplantation. However, the serum creatinine production could decrease secondary to decreased hepatic creatine synthesis in severe liver disease and the eGFR can be overestimated [31]. Thus, the serum creatinine and eGFR in decompensated liver disease should be interpreted cautiously.

Since tenofovir was not available until 2011 June in Taiwan and the renal function was concerned, two nucleoside analogues, LdT and ETV, were used in present study. Both drugs are superior to lamivudine in viral suppression and treatment efficacy [12-15] and both had good safety profiles and tolerability in decompensated liver disease [16-20]. Of note was that the serum creatinine was significantly higher at week 2 than at baseline in ETV group, but not in LdT group. The same observation was noted in eGFR by CKD-EPI with statistically significant decrease in ETV group but not in LdT group. This observation correlated with the results of a recent clinical study of LdT in decompensated liver cirrhosis that the eGFR was significantly increased in LdT group [20]. Although the reason is still unknown, the nucleoside analogue of LdT seemed to be able to slow down or prevent the progression of renal impairment in acute decompensated hepatitis. This might be critical for these patients to gain more time for hepatic recovery and thus increase the chance of survival.

One of the limitations of this study is a small number of cases. This is partly due to the prospective nature of this observational study for validation purpose. Most chronic hepatitis B patients are now under antiviral treatment in Taiwan and thus the incidence of SAE is decreasing. In the future, if more patients can be included, a better clinical correlation can be made.

\section{Conclusions}

In conclusion, increasing serum total bilirubin and deterioration of renal function were important ontreatment predictors of mortality in SAE-related decompensated liver disease. Increasing AFP might indicate good hepatic regeneration and thus constitute a favorable factor for survival. LdT treatment might preserve the renal function in addition to its efficacy in viral suppression.

\section{Abbreviations}

SAE: Severe acute exacerbation; HBV: Hepatitis B virus; ALT: Alanine aminotransferase; INR: International normalized ratio; ETV: Entecavir; 
LdT: Telbivudine; AFP: Alpha-fetoprotein; eGFR: Estimated glomerular filtration rate; MELD: Model for end-stage liver disease; MDRD: Modification of diet in renal disease (MDRD); CKD-EPI: Chronic kidney disease epidemiology collaboration.

\section{Competing interests}

This study was partly supported by a grant from Novartis, Taiwan. Otherwise, the authors have no financial and personal relationships with other people or organizations that could inappropriately influence (bias) their work.

\section{Authors' contributions}

YCC: patient recruitment, acquisition of data, analysis and interpretation of data, statistical analysis, drafting of the manuscript. $\mathrm{CWH}$ : patient recruitment, acquisition of data. MYC: analysis and interpretation of data. CTY: study concept and design, critical revision of the manuscript for important intellectual content, material support, study supervision. All authors read and approved the final manuscript.

\section{Acknowledgements}

This study was supported partly by a grant from Novartis Pharmaceuticals (XMRPG380563) and partly by a grant from Chang Gung Medical Research Program (CMRPG370694).

\section{Author details}

'Department of Gastroenterology-Hepatology, Liver Research Unit, Division of Hepatology, Taipei, Taiwan. ${ }^{2}$ Kidney Research Center, Chang Gung Memorial Hospital, Chang Gung University College of Medicine, Taipei, Taiwan. ${ }^{3}$ Liver Research Center, Chang Gung Memorial Hospital, 199, Tung Hwa North Road, Taipei, Taiwan.

Received: 25 July 2013 Accepted: 29 August 2013

Published: 2 September 2013

\section{References}

1. Liaw YF, Tai DI, Chu CM, Pao CC, Chen TJ: Acute exacerbation in chronic type $B$ hepatitis: comparison between $\mathrm{HBeAg}$ and antibody-positive patients. Hepatology 1987, 7:20-23.

2. Lok AS, Lai CL: Acute exacerbations in Chinese patients with chronic hepatitis B (HBV) infection. Incidence, predisposing factors and etiology. J Hepatol 1990, 10:29-34.

3. Chien RN, Lin CH, Liaw YF: The effect of lamivudine therapy in hepatic decompensation during acute exacerbation of chronic hepatitis $\mathrm{B}$. J Hepatol 2003, 38:322-327.

4. Wong WW, Chan HL: Severe acute exacerbation of chronic hepatitis B: a unique presentation of a common disease. J Gastroenterol Hepatol 2009, 24:1179-1186.

5. Sarin SK, Kumar A, Almeida JA, Chawla YK, Fan ST, Garg H, de Silva HJ, Hamid SS, Jalan R, Komolmit P, Lau GK, Liu Q, Madan K, Mohamed R, Ning Q, Rahman S, Rastogi A, Riordan SM, Sakhuja P, Samuel D, Shah S, Sharma BC, Sharma P, Takikawa Y, Thapa BR, Wai CT, Yuen MF: Acute-on-chronic liver failure: consensus recommendations of the Asian Pacific Association for the study of the liver (APASL). Hepatol Int 2009, 3:269-282.

6. Vickers C, Neuberger J, Buckels J, McMaster P, Elias E: Transplantation of the liver in adults and children with fulminant hepatic failure. $J$ Hepatol 1988, 7:143-150.

7. Chan HL, Tsang SW, Hui Y, Leung NW, Chan FK, Sung JJ: The role of lamivudine and predictors of mortality in severe flare-up of chronic hepatitis B with jaundice. J Viral Hepat 2002, 9:424-428.

8. Yuen MF, Sablon E, Hui CK, Li TM, Yuan HJ, Wong DK, Doutreloigne J, Bogaerts V, Wong BC, Fan ST, Lai CL: Prognostic factors in severe exacerbation of chronic hepatitis B. Clin Infect Dis 2003, 36:979-984.

9. Tsubota A, Arase Y, Suzuki Y, Suzuki F, Hosaka T, Akuta N, Someya T, Kobayashi M, Saitoh S, Ikeda K, Kumada H: Benefit of lamivudine therapy and factors associated with clinical outcome in spontaneous severe acute exacerbation of chronic hepatitis B virus infection. Intervirology 2004, 47:335-341.

10. Tsubota A, Arase $Y$, Suzuki $Y$, Suzuki F, Sezaki H, Hosaka T, Akuta N, Someya T, Kobayashi M, Saitoh S, Ikeda K, Dumada H: Lamivudine monotherapy for spontaneous severe acute exacerbation of chronic hepatitis B. J Gastroenterol Hepatol 2005, 20:426-432.
11. Dai CY, Chuang WL, Hou NJ, Lee LP, Hsieh MY, Lin ZY, Chen SC, Huang JF, Hsieh MY, Wang LY, Tsai JF, Chang WY, Yu ML: Early mortality in Taiwanese lamivudine-treated patients with chronic hepatitis B-related decompensation: evaluation of the model for end-stage liver disease and index scoring systems as prognostic predictors. Clin Ther 2006, 28:2081-2092

12. Chang TT, Gish RG, de Man R, Gadano A, Sollano J, Chao YC, Lok AS, Han KH, Goodman Z, Zhu J, Cross A, DeHertogh D, Wilber R, Colonno R, Apelian D, BEHoLD Al463022 Study Group: A comparison of entecavir and lamivudine for HBeAg-positive chronic hepatitis B. N Engl J Med 2006, 354:1001-1010.

13. Lai CL, Shouval D, Lok AS, Chang TT, Cheinquer H, Goodman Z, DeHertogh D, Wilber R, Zink RC, Cross A, Colonno R, Fernandes L, BEHoLD Al463027 Study Group: Entecavir versus lamivudine for patients with HBeAg-negative chronic hepatitis B. N Engl J Med 2006, 354:1011-1020.

14. Lai CL, Gane E, Liaw YF, Hsu CW, Thongsawat S, Wang Y, Chen Y, Heathcote EJ, Rasenack J, Bzowej N, Naoumov NV, Di Bisceglie AM, Zeuzem S, Moon YM, Goodman Z, Chao G, Constance BF, Brown NA, Globe Study Group: Telbivudine versus lamivudine in patients with chronic hepatitis B. N Engl J Med 2007, 357:2576-2588.

15. Liaw YF, Gane E, Leung N, Zeuzem S, Wang Y, Lai CL, Heathcote EJ, Manns M, Bzowej N, Niu J, Han SH, Hwang SG, Cakaloglu Y, Tong MJ, Papatheodoridis G, Chen Y, Brown NA, Albanis E, Galil K, Naoumov NV GLOBE Study Group: 2-Year GLOBE trial results: telbivudine Is superior to lamivudine in patients with chronic hepatitis B. Gastroenterology 2009, 136:486-495.

16. Liaw YF, Raptopoulou-Gigi M, Cheinquer H, Sarin SK, Tanwandee T, Leung N, Peng CY, Myers RP, Brown RS Jr, Jeffers L, Tsai N, Bialkowska J, Tang S, Beebe $S$, Cooney E: Efficacy and safety of entecavir versus adefovir in chronic hepatitis $B$ patients with hepatic decompensation: a randomized, open-label study. Hepatology 2011, 54:91-100.

17. Liaw YF, Sheen IS, Lee CM, Akarca US, Papatheodoridis GV, Suet-Hing Wong F, Chang TT, Horban A, Wang C, Kwan P, Buti M, Prieto M, Berg T, Kitrinos K, Peschell K, Mondou E, Frederick D, Rousseau F, Schiff ER: Tenofovir disoproxil fumarate (TDF), emtricitabine/TDF, and entecavir in patients with decompensated chronic hepatitis B liver disease. Hepatology 2011, 53:62-72.

18. Shim JH, Lee HC, Kim KM, Lim YS, Chung YH, Lee YS, Suh DJ: Efficacy of entecavir in treatment-naïve patients with hepatitis $B$ virus-related decompensated cirrhosis. J Hepatol 2010, 52:176-182.

19. Wong W, Wong GL, Yiu KK, Chim AM, Chu SH, Chan HY, Sung JJ, Chan HL. Entecavir treatment in patients with severe acute exacerbation of chronic hepatitis B. J Hepatol 2011, 54:236-242.

20. Chan HL, Chen YC, Gane EJ, Sarin SK, Suh DJ, Piratvisuth T, Prabhakar B, Hwang SG, Choudhuri G, Safadi R, Tanwandee T, Chutaputti A, Yurdaydin C, Bao W, Avila C, Trylesinski A: Randomized clinical trial: efficacy and safety of telbivudine and lamivudine in treatment-naïve patients with HBV-related decompensated cirrhosis. J Viral hepat 2012, 19:732-743.

21. United network for organ sharing. MELD/PELD calculator documentation. http://www.unos.org/docs/ MELD_PELD_Calculator_Documentation.pdf. Accessed April 2011.

22. Levey AS, Bosch JP, Lewis JB, Greene T, Rogers N, Roth D: A more accurate method to estimate glomerular filtration rate from serum creatinine: a new prediction equation. Modification of diet in renal disease study group. Ann Intern Med 1999, 130:461-470.

23. Levey AS, Stevens LA, Schmid CH, Zhang Y, Castro AF III, Feldman HI, Kusek JW, Eggers $P$, Lente FV, Greene T, Coresh J: A new equation to estimate glomerular filtration rate. Ann Intern Med 2009, 150:604-612.

24. Garg H, Sarin SK, Kumar M, Garg V, Sharma BC, Kumar A: Tenofovir improves the outcome in patients with spontaneous reactivation of hepatitis B presenting as acute-on-chronic liver failure. Hepatology 2011, 53:774-780

25. Liaw YF, Chu CM, Huang MJ, Sheen IS, Yang CY, Lin DY: Determinants for hepatitis B e antigen clearance in chronic type B hepatitis. Liver 1984, 4:301-306.

26. Karvountzis $G G$, Redeker AG: Relation of alpha-fetoprotein in acute hepatitis to severity and prognosis. Ann Intern Med 1974, 80:156-60.

27. Bernuau D, Poliard A, Feldmann G: In situ cellular analysis of a-fetoprotein gene expression in regenerating rat liver after partial hepatectomy. Hepatology 1988, 8:997-1005. 
28. Yang SS, Chen KS, Lai YC, Wu CH, Chen TK, Lee CL, Chen DS: Decreasing serum alpha-fetoprotein levels in predicting poor prognosis of acute hepatic failure in patients with chronic hepatitis B. J Gastroenterol 2002, 37:626-632.

29. Schmidt $L$, Dalhoff $K$ : Alpha-fetoprotein is a predictor of outcome in acetaminophen-induced liver injury. Hepatology 2005, 41:26-31.

30. Betrosian AP, Agarwal B, Douzinas EE: Acute renal dysfunction in liver diseases. World I Gastroenterol 2007, 13:5552-5559.

31. Sherman DS, Fish DN, Teitelbaum I: Assessing renal function in cirrhotic patients: Problems and pitfalls. Am J Kidney Dis 2003, 41:269-278.

doi:10.1186/1756-0500-6-349

Cite this article as: Chen et al:: On-treatment mortality predictors in chronic hepatitis B patients experiencing severe acute exacerbation: a prospective observational study. BMC Research Notes 2013 6:349.

\section{Submit your next manuscript to BioMed Central and take full advantage of:}

- Convenient online submission

- Thorough peer review

- No space constraints or color figure charges

- Immediate publication on acceptance

- Inclusion in PubMed, CAS, Scopus and Google Scholar

- Research which is freely available for redistribution 